\title{
Rевенсн Автіске: Influence of weed management practices on yield and economics of aerobic rice under different seeding methods
}

\section{CH. PRASHANTHI, P. LAXMINARAYANA AND G.E.CH. VIDYA SAGAR}

Article Chronicle: Received :

19.07.2017;

Accepted :

03.08.2017

KEY WoRds:

Aerobic rice, Weed index, Yield,

Economics

Author for correspondence :

\section{CH. PRASHANTHI}

Department of

Agronomy, College of

Agriculture, Professor

Jayashankar Telangana

State Agricultural

University,

Rajendranagar,

HYDERABAD

(TELANGANA) INDIA

Email : prashanthiagrico

@ gmail.com

See end of the article for

authors' affiliations
SUMMARY : A field experiment was conducted during the Kharif, 2014 at College Farm, Professor Jayashankar Telangana State Agricultural University, Hyderabadto study the bio-efficacy of variousherbicides on weeds, yield and economics of direct seeded rice. The weed flora emerged during experimentation were: grasses like Echinocloa colonam L., Cynodon dactylon L., Eleusine indica, sedges like Cyperus rotundus L, and broad-leaved weeds like Eclipta alba L., Commelina bengalensis L., Ipomoea purpurea, Alternanthera sessillis, Physalis minima, Bacopa monnieri, Cyanotis cristata, Corchorus, Phyllanthus niruri, Ageratum conyzoides.Among seeding methods the highest gross returns (Rs.47280), net returns (Rs.17544) and B: C ratio (1.57) were obtained with line sowing than broadcasting.Among weed management practices highest gross returns (Rs.47770) were with $\mathrm{T}_{6}$ treatment and highest net returns (Rs.15826) with $\mathrm{T}_{5}$ treatment whereas highest $\mathrm{BC}$ ratio (1.56) with with $\mathrm{T}_{3}$ and $\mathrm{T}_{4}$ treatments was obtained which were superior to other treatments.

How to cite this article : Prashanthi, Ch., Laxminarayana, P. and Sagar, G.E.Ch. Vidya (2017). Influence of weed management practices on yield and economics of aerobic rice under different seeding methods. Agric. Update, 12(TECHSEAR-7) : 1828-1832; DOI: 10.15740/HAS/AU/12.TECHSEAR(7)2017/1828-1832. 